\title{
The Impact of Supply Chain Collaboration on Performance in Automotive Industry: Empirical Evidence
}

\author{
Jamal Ahmed Al-Doori \\ Business Administration, Al-Abliyya Amman University (Jordan) \\ J.aldouri@ammanu.edu.jo
}

Received: January 2019

Accepted: March 2019

\begin{abstract}
:
Purpose: Indeed due to global advancement, rapid technological innovation, and enhancing regional influence, supply chain (SC) has become an essential element. Now, competition has shifted from organization to industry level; any disruption can not only disturb organization but also affect the whole industry. Although Pakistan is agriculture land still industry sector is supporting more than half the population, especially the automotive sector is the highest growing sector. Due to regional and economic shift toward China and India, this sector is facing numerous problems. Only thirteen large-scale automotive organizations are operational by creating collaboration among them many issues can be resolved. Supply chain collaboration has dogged the performance in various industries and in various regions. The aim of this study is to explore the potential benefits of supply chain collaboration toward achieving operational performance.
\end{abstract}

Design/methodology/approach: This is an empirical investigation conducting among the supply chain department of automotive industries in Pakistan. Data were collected from 232 members of the supply chain that include suppliers, manufacturers, and distributors. Factor analysis and multiple regressions through SPSS have been used for data analysis.

Findings: The finding of this study reveals that two supply chain management approaches information sharing (IS), joint decision making (JDM) significantly effect, while Electronic Data Interchange (EDI) does not have a significant effect on operational performance.

Research limitations: This study consists only three approaches, the next study should include more approaches. Secondly, this study is limited to the automotive sector.

Practical implications: This study will help the managers of the automotive industry in making their operation smooth by applying information sharing, joint decision making, and electronic data interchange.

Originality/value: First novelty of this study is the implementation of supply chain collaboration for developing country especially for Pakistan. Secondly, this study seed collaboration as communication and include all aspects of communication like formal communication, informal communication.

Keywords: supply chain, supply chain collaboration, operational performance

\section{To cite this article:}

Al-Doori, J.A. (2019). The impact of supply chain collaboration on performance in automotive industry:

Empirical evidence. Journal of Industrial Engineering and Management, 12(2), 241-253.

https://doi.org/10.3926/jiem.2835https://doi.org/10.3926/jiem.2835 


\section{Introduction}

The objective of supply chain management is to the mountain the sale either form goods or services while keeping the expenditures and expenses minimum. Previous logistics focused only on procurement, maintenance, inventory management, and distribution. Supply chain adds values like new product development, marketing, customer services, and finance. Now supply chain has its own objectives like customer satisfaction and sustainable organizational performance (Hassan, Zaharudin \& Yunus, 2015). The rapid growth in the global supply chain requires interconnectedness among stakeholders. As a result, a high level of interdependency and complexity develop in supply chain (Christopher, Mena, Khan \& Yurt, 2011; Elkins, Handfield, Blackhurst \& Craighead, 2005; Kamalahmadi \& Parast, 2016). Empirical studies have been proved that supply chain collaboration increased performance (Sheu, Yen \& Chae, 2006). Likewise, another example will add the importance of collaboration, Dow Chemical Company (2011) the policy of dove chemical company is proposing a plane with the partners. Like Dow with their logistics providers in North America, who deal $90 \%$ of Dow's shipment, develop a highway security network that shares intelligence information, discuss best approaches and generate a mutual security plane for safe shipment

Performance measure is an indicator that establishes how well an organization accomplishes its goals; it may include market orientation, customer satisfaction, financial performance or etc. previous performance has been measured in numerous methods like firm performance, operational performance, and financial performance. However, it has been established that competition is no more among organizations but among supply chain. Thus, to compete globally, it is essential to include all members and performance should be measured on supply chain level. An organization with better supply chain can keep the business smooth, efficient and effective (Basu, Jeyasingam, Habib, Letchmana \& Ravindran, 2017). In order to achieve efficiency and effectiveness managers must establish a completive supply chain approaches, there are various approaches to that positively affect the performance, the most effective is considered is supply chain collaboration (Seo, Dinwoodie \& Roe, 2015).

Although Pakistan is an agriculture land but still manufacturing is playing a vital role in county growth. Especially, the automotive industry recorded the highest growth of 23.43 percent (compared to 17.06 percent last year) (Pakistan Economic Survey, 2016). The automotive sector is facing very high risk locally as well as globally (Manners-Bell, 2014). Auto companies usually outsource their various spare parts manufacturing to different suppliers from all over the world (Afzal, 2011). In the automobile sector, there has been a surge in productions of all its sub-sectors except the farm tractors and jeeps during the period July-March FY 2016. Remarkable growth has been witnessed in buses which are recorded at 82 percent, LCVs 68.5 percent, Trucks 41.6 percent, Cars 30.2 percent and two/three wheelers 21 percent during July-March FY 2016 as compared to corresponding period last year. However, during July-March FY 2016, farms tractors and jeeps production declined by 38.6 percent and 28.4 percent (Pakistan Economic Survey, 2016).

Conclusively, after realizing Pakistan economic situation and present development in the automotive industry it can be concluded that effective supply chain is essential. However, to make the supply chain effective, efficient and achieve the best operational performance supply chain collaboration need to be more improved. This study has empirically verified three supply chain collaboration approaches namely, information sharing, joint decision making, and Electronic Data Interchange and revealed that all three approaches have a positive and significant effect of operational performance.

\section{Literature Review}

Supply chain is a very new field; it has its roots in every aspect of the organizations. Previous it was regarded as logistic and its functions only flowed of goods. With the passage of time researchers and academicians add value like, marketing, inventory management, finance, promotions, or even new product development. According to Shukla, Garg and Agarwal, (2011) "Supply Chain Management is the management of material, money, men, and information within and across the supply chain to maximize customer satisfaction and to get an edge over competitors". It also includes suppliers, logistics provider, customers, and other members so first this it deals not only supply but also demand and other sides and secondly, it is not a simple chain but has become a complex 
network (Shahbaz, Rasi, Bin \& Rehman, 2017; Whitten, Kenneth \& Zelbst, 2012). Thus, for better understanding, it is essential to understand all member of supply chain that has either indirect or indirect effects of performance.

\subsection{Operational Performance}

The performance is "A set of metrics used to quantify the efficiency and effectiveness of supply chain processes and relationships, spanning multiple organizational functions and multiple firms and enabling supply chain orchestration" (Maestrini, Luzzini, Maccarrone \& Caniato, 2017). The aim of every organization is to enhance the performance but for improvement, they must need to measure it accurately first (Gunasekaran \& Kobu, 2007). Previously performance was measured by cost with the passage of time more financial indicator were added like return on asset, return on investment, sale and etc. (Anand \& Grover, 2015). Only financial indicators are not enough for measure overall and accurate performance, consequently, with the intent of balance scorecard approach some operational indicators were added (Attia, 2015; Gunasekaran, Patel \& McGaughey, 2004; Shahbaz, Rasi, Zulfakar, Bin \& Asad, 2018). Other approaches also added values in measuring supply chain like quantitative or qualitative measures, strategic, tactical and operational measures and etc. (Arzu-Akyuz \& Erman-Erkan, 2010). A comprehensive review and revealed that for the good performance measure all the members should be considered, performance measure should consider both financial and non-financial items, all the levels of supply chain must be considered and all process of supply chain should be included so the performance should be measured by operational performance (Shahbaz, Rasi, Zulfakar, Bin, Abbas \& Mubarak, 2018).

Meanwhile, researchers had used many ways to measure the effects of risk sources and supply chain practices with different means like firm or organizational performance (Cook, Heiser \& Sengupta, 2011; Shukla, Garg \& Agarwal, 2013), product performance, operational performance (Kauppi, Longoni, Caniato \& Kuula, 2016; Sukati, Hamid \& Baharun, 2013), logistic performance (Effendi, 2015), financial performance (Li, Fan, Lee \& Cheng, 2015) or operational performance(Ahmad \& Saifudin, 2014; Chen, 2012; Sukati, Hamid, Baharun \& Yusoff, 2012; Sundram, Chandran \& Bhatti, 2016). Nevertheless, indicators to measure above mention performance are alike. SCM had been measured by operational performance and its indicators were quality performance, flexibility performance, customer service, delivery performance and cost performance (Kauppi et al., 2016). Effendi (2015) has use logistic effect for SCM and its metric consisted in order fill rate, order fulfillment lead time, operations flexibility, inventory turnover, and total logistics cost. SCM has been measured SCM with organizational performance and its dimension was profit, cost, ROI and sale (Florian \& Constangioara, 2014). It can be concluded that SCM performance had been measured by various ways like operational, organizational, firm, financial measures. A model has been developed for measuring performance and revealed that for measuring overall performance, these items should be considered cost, quality, flexibility, customer satisfaction, capacity, time, consistency (Shahbaz, Rasi, Zulfakar, Bin, Abbas \& Mubarak, 2018). Thus, this study will consider all the requirement of better operational performance.

\subsection{Supply Chain Management Approaches}

SCM approaches have been defined in various ways like according to (Basu et al., 2017) "SCM approaches are used to achieve organizations short term and long term goals such as to enhance productivity, control inventory, reduce waste, increase market share and sustain growth". After measuring the performance now there is a question; how to improve it? The literature on SCM has proposed and verified number of approaches and strategies that have a positive effect on performance like just in time, lean/agile/hybrid, integration, flexibility, and supply chain collaboration. However, due to globalization, it is hard for an organization to sustain alone, supply chain collaboration has become an essential part of business practices nowadays (Chopra \& Sodhi, 2004; Shahbaz, Rasi, Bin \& Sohu, 2018). If an organization wants to the competition it must focus on internally and externally (Basu et al., 2017).

Several dimensions had been proposed for SCM approaches in the literature. (Sezen, 2008) has explored SC integration, SC design and IS and revealed that none of the approaches affected flexibility performance and only SC design affected resource performance and output performance. (Cook et al., 2011) had developed and verified five dimensions that are long-range relationships, information sharing, leveraging the internet, advanced planning techniques and supply and distribution network structures and found a positive relationship with organizational performance. In addition (Sundram, Ibrahim \& Govindaraju, 2011) has investigated SCM approaches by customer 
and supplier and relationships, postponement, agreed goals and vision, level and quality of IS and reward/risk sharing. This study found that all have a positive relationship except customer relationship. Another study investigates internal integration, customer integration, and supplier integration and found that customer integration did not the significant positive impact of the performance. Thus, many studies have been conducted on SCM approaches that have revealed a positive effect of performance.

The rapid growth in the global supply chain requires interconnectedness among stakeholders. As a result, a high level of interdependency and complexity develop in the supply chain (Christopher et al., 2011; Elkins et al., 2005; Kamalahmadi \& Parast, 2016). Empirical studies have been proved that supply chain collaboration increased performance (Marín-García, Alfalla-Luque \& Machuca, 2018; Sheu et al., 2006). Likewise, another example will add the importance of collaboration, Dow Chemical Company (2011) the policy of dove chemical company is proposing a plane with the partners. Like Dow with their logistics providers in North America, who deal 90\% of Dow's shipment, develop a highway security network that shares intelligence information, discuss best approaches, and generate a mutual security plane for safe shipment. According to Ataseven and Nair, (2017) information sharing, joint decision making (JDM) and teamwork are the major dimensions of SCM approaches. By review the literature it can be concluded that information sharing, joint decision making, and Electronic Data Interchange are the most important approaches and additionally these approaches have also empirically verified in many countries and many industries.

\subsection{Information Sharing}

IS defined as "the willingness to make strategic and tactical data such as inventory levels, forecasts, sales promotion, strategies, and marketing strategies available to firms forming supply chain nodes" (Cao \& Zhang, 2013). The ability to see from one side of the channel to last is crucial, information is assumed as blood for SC collaboration(Christopher, 2011; Shahbaz, Kazi, Othman, Javaid, Hussain \& Rasi, 2019). The aim of IS is to improve the efficiency and effectiveness in the whole network of organizations and finally enhance not only the firm performance but also the operational performance (Qrunfleh, 2010). IS may also include logistic, customer, quality, time, market changes, design or uncertainty (Singh, 2013). IS has been investigating in multiple industries and regions and revealed that it has a major contribution to enhancing operational performance (Abdallah, Obeidat \& Aqqad, 2014; Effendi, 2015). IS positive affects performance in many ways like enhanced service levels, customer responsiveness, decreased costs, and reduced levels of complexity (Flynn, Huo \& Zhao, 2010).

Huo, Zhao and Zhou, (2014) has studies IS with suppliers, customers and internal in Chines manufacturing and revealed that all have a positive effect on operational performance and internal IS also has a positive relationship with external IS. IS has a positive effect on operational performance but not significantly in the manufacturing sector of Turkey (Sezen, 2008; Shahbaz, Chandio, Oad, Ahmed,\& Ullah, 2018). The today supply chain has become more fragile and risks have become a serious concern. (Cao, Vonderembse, Zhang \& Ragu-Nathan, 2010) did a comprehensive literature review and found that IS has not only a positive effect on performance but also a good tool for reducing uncertainty. Based on the literature review below hypothesis has been developed.

H1: Information sharing has a positive effect on operational performance.

\subsection{Joint Decision Making}

JDM defined as the "process by which supply chain partners coordinate activities in supply chain planning and operations for optimizing the supply chain benefits (Cao \& Zhang, 2013) it includes plans, combines information, resolves problems and develops rules and regulation and procedures. An effective strategic coalition and worthy relationship with customers and suppliers are required and It should consist of trust, loyalty and positive relationship (Basu et al., 2017). The aim of JDM is to align partners and to synchronize decisions on order placement, inventory replenishment and order delivery (Cao et al., 2010). Meanwhile, every partner has its own objectives and goals, so it is sometimes very hard to come on mutual points that may cause uncertainty (Kauppi et al., 2016), to reduce this uncertainty JDM has become an important strategy for today business.

Furthermore, it has also empirically verified that JDM has a positive effect on operational performance (Effendi, 2015; Ha, Park \& Cho, 2011; Shukla et al., 2013). Wiengarten, Humphreys, Cao, Fynes \& McKittrick (2010) JDM 
has a positive relationship with operational performance when the quality of information is high. Meanwhile, (Effendi, 2015) revealed that JDM with suppliers and customers improves logistic efficiency. JDM at strategic, tactical and operational level improves the magnitude of relationship quality, strength, and closeness that ultimately enhance operational performance (Jüttner \& Maklan, 2011). Hence, based on the literature review following hypothesis has been drawn.

H2: Joint decision making has a positive effect on operational performance.

\subsection{Electronic Data Interchange}

Electronic Data Interchange (EDI) and now the Internet have enabled partners in the supply chain to act upon the same data, at the same time with minimum resources (Christopher, 2011). It is defined as a set of specifications for exchanging standard business documents such as purchase orders, invoices, and bills of lading over computer networks. EDI is defined as the direct computer-to-computer transfer of information (possibly through a third party) between independent organizations (Arshinder, Kanda \& Deshmukh, 2006). Electronic data interchange provides visibility to data across supply networks, finally, process management applications, and server-to-server links that enable true and real-time channel information and transaction harmonization. From this level, the degree of collaboration strengthens with increasing communication to facilitate joint operations and coordination, where companies in the supply chain use the competencies of network partners, to cooperation where channel partners (Ross, 2011). EDI has numerous advantages like faster information flow, quick payments, receive standardized data, easy tracking of orders, visibility of information to all members and easy updating of received data (Arshinder et al., 2006). In various studies, it has been revealed that EDI has positive and significant effects on performance (Cook et al., 2011; Shukla, 2016; Shukla et al., 2013). On the basis of the above literature below hypothesis has been developed.

H3: Electronic Data Interchange has a positive effect on operational performance.

\subsection{Research Framework}

After exhaustive literature review (Figure 1) framework has been developed. Figure 1 shows the proposed conceptual framework that consists of three independent variables, information sharing, joint decision making, and electronic data interchange, and a dependent variable operational performance.

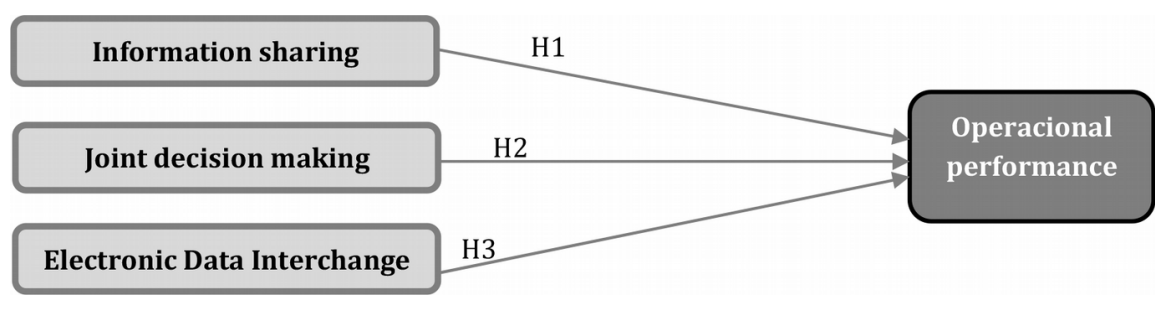

Figure 1. Research framework

\section{Methodologies}

The aim of this study is to find how much supply chain collaboration approaches have effects on operational performance. This is quantitative study; survey method has been used for data collection. Supply chain collaboration is has been applied in numerous countries and in various industries, extensive work has been done in recent years. After a comprehensive literature review, this study adapts questionnaire from different previous studies according to best match with industry and demographic position. Likert scale 5 has been used and questionnaires have been distributed through the internet to all respondents. Below Table 1 is describing four variables of information sharing, joint decision making, electronic data interchange, and operational performance according to their sub-dimensions and references. 


\begin{tabular}{|c|c|c|}
\hline Variable & Items & References \\
\hline \multirow{6}{*}{$\begin{array}{l}\text { Information } \\
\text { sharing }\end{array}$} & The organization informs its trading partners in advance of changing needs & \multirow{6}{*}{$\begin{array}{l}\text { Sundram et al. } \\
(2016)\end{array}$} \\
\hline & $\begin{array}{l}\text { Organization's trading partners share proprietary information with your } \\
\text { organization }\end{array}$ & \\
\hline & $\begin{array}{l}\text { Organization's trading partners keep your organization fully informed about issues } \\
\text { that affect its business }\end{array}$ & \\
\hline & $\begin{array}{l}\text { Organization and it's trading partners exchange information that helps the } \\
\text { establishment of business planning }\end{array}$ & \\
\hline & $\begin{array}{l}\text { Organization's trading partners share business knowledge of core business } \\
\text { processes }\end{array}$ & \\
\hline & $\begin{array}{l}\text { Organization and it's trading partners keep each other informed about events or } \\
\text { changes that may affect the other partners }\end{array}$ & \\
\hline \multirow{7}{*}{$\begin{array}{l}\text { Joint decision } \\
\text { making }\end{array}$} & Participating in the sourcing decisions of your suppliers & \multirow{4}{*}{$\begin{array}{l}\text { Jayaram, Tan and } \\
\text { Nachiappan (2010) }\end{array}$} \\
\hline & Participating in the marketing efforts of your customers & \\
\hline & $\begin{array}{l}\text { Involving all members of your firm's supply chain in your } \\
\text { product/service/marketing plans }\end{array}$ & \\
\hline & $\begin{array}{l}\text { Contacting the end users of your products to get feedback on } \\
\text { performance/customer service }\end{array}$ & \\
\hline & Shared operational decision making & \multirow{3}{*}{ Effendi (2015) } \\
\hline & The willingness of collaborative problem solution & \\
\hline & The willingness of collaboration in strategic decision making & \\
\hline \multirow{5}{*}{$\begin{array}{l}\text { Electronic data } \\
\text { interchange }\end{array}$} & Creating linkage with suppliers through information technology & \multirow{5}{*}{$\begin{array}{l}\text { Qi, Huo, Wang and } \\
\text { Yeung (2017) }\end{array}$} \\
\hline & Creating linkage with customers through information technology & \\
\hline & Enterprise application integration among internal functions & \\
\hline & Integrative inventory management & \\
\hline & Data integration among internal functions & \\
\hline \multirow{5}{*}{$\begin{array}{l}\text { Operational } \\
\text { performance }\end{array}$} & Quality performance & \multirow{5}{*}{ Kauppi et al. (2016) } \\
\hline & Flexibility performance & \\
\hline & Customer service & \\
\hline & Delivery speed & \\
\hline & Cost performance & \\
\hline
\end{tabular}

Table 1. Questionnaire items with references

\subsection{Sampling and Data Collection}

The target of the population in this study consists of automotive companies in Pakistan. Information sharing, joint decision making, and electronic data interchange are independent variables and operational performance is a dependent variable. The samples of this study are members of automotive companies including manufacturing, assembling, distributer, retailers, and suppliers. Data were collected through questionnaires. The questionnaires were distributed to the members through self-administered surveys and the email. The sample size was 232 due to limited time and economic restraints. This study considered the target respondents having experience for more than 10 years. The automotive industry is producing seven types of vehicles that are Cars, LCVs, Jeeps, Buses, Trucks, Farm Tractors, Two/Three Wheelers, Figure 2 shows that categories of respondents according to vehicles production. Whereas, Figure 3 explain the distribution of respondents accords to their working experience and vehicles manufacturing. 


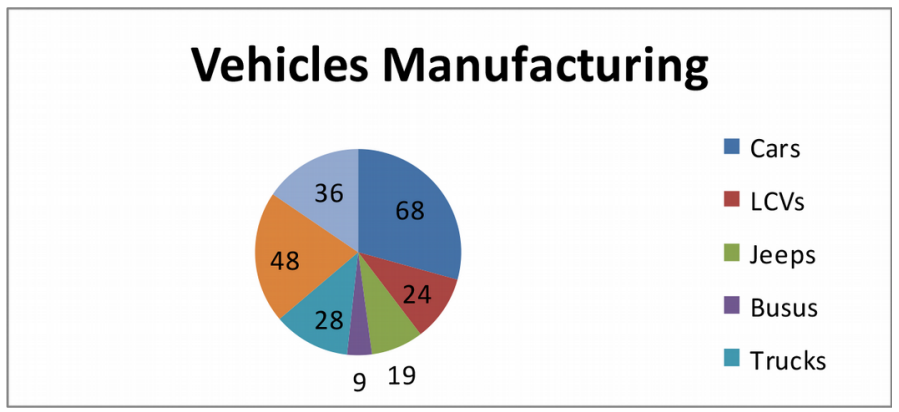

Figure 2. Number of respondents according to vehicle manufacturing

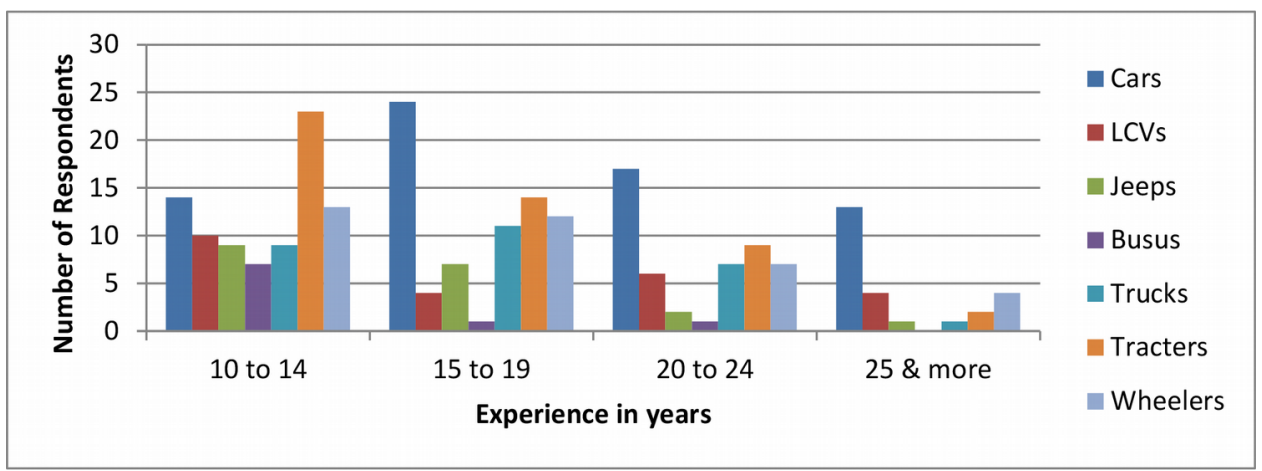

Figure 3. Number of respondents according to their experience and vehicle manufacturing

\subsection{Data Analysis and Discussion}

Data has been analyzed through SPSS 23 version. First special codes have been assigns to analysis then the manual screen of data has been performed and responses with high mission values and same responses have been deleted. Furthermore, by the histogram, Q-Q plot and skewness and kurtosis data have been clean from missing values and outliers. Additionally, data reliability has been checked through Cronbach's $\sigma$. Table 2 presents the value of Cronbach's $\sigma$, mean and standard deviations. For the independent variables, information sharing yield the highest mean is 3.868, joint decision making mean is 3.906, EDI mean is 4.162 and at the last, Operational performance mean is 4.643 .

Correlation is the relationship among variables; one tail Pearson correlation has been calculated to determine the relationship between supply chain collaboration approaches and operational performance. Analysis of correlation shows that all three relationships are significant it can be seen in Table 3. The correlations between information sharing and operational performance are $0.726^{* *}$, that mean there is a significant relationship between the two. Correlation of joint stock making is $0.446^{* *}$ indicates a positive relationship among members but this relationship is not strong. The value of correlation of EDI is $0.590^{* *}$ that also explain the strong relation between Edi and operational performance.

\begin{tabular}{|l|r|r|r|}
\hline \multicolumn{1}{|c|}{ Variable } & Cronbach's $\alpha$ & \multicolumn{1}{c|}{ Mean } & \multicolumn{1}{c|}{ SD } \\
\hline Information Sharing & .886 & 4.2444 & .51143 \\
\hline Joint Decision Making & .783 & 4.0586 & .54648 \\
\hline Electronic data interchange & .785 & 3.0189 & .90359 \\
\hline Operational performance & .692 & 3.9617 & .59285 \\
\hline
\end{tabular}

Table 2. Cronbach's $\sigma$ coefficient, means and standard deviations 


\begin{tabular}{|l|r|r|r|r|}
\hline \multicolumn{1}{|c|}{ Variable } & \multicolumn{1}{c|}{ IS } & \multicolumn{1}{c|}{ JDM } & \multicolumn{1}{c|}{ P/RS } & \multicolumn{1}{c|}{ SCP } \\
\hline Information Sharing & 1 & & & \\
\hline Joint Decision Making & .119 & 1 & & \\
\hline Electronic data interchange & $.458^{* *}$ & $.510^{* *}$ & 1 & \\
\hline Operational performance & $.726^{* *}$ & $.446^{* *}$ & $.590^{* *}$ & 1 \\
\hline
\end{tabular}

*Correlation is significant at the 0.05 level (1-tailed).

${ }^{* *}$ Correlation is significant at the 0.01 level (1-tailed).

Table 3. Correlation analysis

\begin{tabular}{|c|c|c|c|c|c|c|c|}
\hline \multirow[b]{2}{*}{ Model } & \multicolumn{2}{|c|}{$\begin{array}{l}\text { Unstandardized } \\
\text { Coefficients }\end{array}$} & \multirow{2}{*}{$\begin{array}{c}\text { Standardized } \\
\text { Coefficients }\end{array}$} & \multirow[b]{2}{*}{$\mathbf{R}^{2}$} & \multirow[b]{2}{*}{$\mathrm{t}$} & \multirow[b]{2}{*}{ Sig. } & \multirow[b]{2}{*}{ Results } \\
\hline & $\mathbf{B}$ & Std. Error & & & & & \\
\hline a (Constant) & 1.451 & .338 & & & 4.290 & .000 & \\
\hline Information sharing & .678 & .076 & .163 & .580 & 2.485 & .000 & Supported \\
\hline Joint decision making & .559 & .075 & .390 & .516 & 5.672 & .000 & Supported \\
\hline Electronic data interchange & .623 & .041 & -.004 & .397 & -.059 & .000 & Not Supported \\
\hline
\end{tabular}

a. Dependent Variable: Operational performance

Table 4. Regression analysis

Furthermore, multiple regression analyses are first confirmed by testing the assumptions of normality, linearity, homoscedasticity, and independence of residuals, revealing that the residuals are normally distributed. Multiple regression analysis allows for determining the degree of strength and the direction of the linear relationship among research variables (Shukla, 2016). Regression analysis in Table 4 indicates the relationship among independent and dependent variable. Information sharing, joint decision making, and EDI regressed against operational performance and the variance accounted for, $\mathrm{R}^{2}(.580), \mathrm{R}^{2}(.516), \mathrm{R}^{2}(.397)$, respectively and these figures show that $(58 \%)$ of sharing information, $(51.6 \%)$ of joint decision making and $(39.7 \%)$ of EDI can be increased performance of Automotive industry in Pakistan.

Multiple linear regression analyses are employed to develop models relating the three independent variables and one dependent variable. In the first model, the dependent variable is operational performance, the model seems to be reliable ( $\mathrm{p}$-value for $\mathrm{F}<0.01$ and adjusted $\mathrm{R}$-square of 0.130 . The significance of all the independent variable was found $\mathrm{P}<0.05$, which is 0.000 . The result shows the variables of information sharing, joint decision making, and electronic data interchange jointly explain the variance $\left(\mathrm{r}^{2}\right)$ of supply chain management. Beta coefficient values indicate the contribution of the individual predictor in the model. The beta for information sharing is 0.678 . This mean when one unit increase in information sharing, the overall performance of the supply chain will increase by 0.678. The significance was found between joint decision making and operational performance and indicates beta value .559 which shows the relationship between them. The beta of electronic data interchange is .623 which mean when one unit increase due to EDI with members, the overall performance of the supply chain will increase by 0.623. There is a significant relationship between these three variables of information sharing, joint decision making and but not with electronic data interchange with supply chain management hence proved that H1, H2 are accepted while $\mathrm{H} 3$ is not accepted.

\section{Discussions}

This study focuses on the relationship between information sharing, joint decision making, Electronic Data Interchange, and operational performance in the context of the automotive industry in Pakistan. The findings of the study indicate that the independent variable like information sharing, joint decision making, and EDI positively influences operational performance. These outcomes are reliable with extant supply chain management literature (Cao \& Zhang, 2011; Effendi, 2015). This study suggests that the implementation of supply chain collaboration 
approaches among automotive industries is also an important predictor, similar to other developed countries. It will give some benefit to the individual, both suppliers and buyers organization and other researchers. This paper made a number of significances and discussion of the study. Firstly, all three factors improve operational performance.

Researchers can use the finding of this study to produce an idea for further studies, and supply chain managers are able to identify specific operational performance that has the higher perspective to increase the performance of the automotive industry. Next, making collaboration with supply chain partners can help to boost operational performance. Managers of the supplier firm need to collaborate with the managers from the buyer firm in terms of making several supply chain decisions. Moreover, connecting managers across functional and organizational boundaries and providing them with relevant, accurate, and timely information reduces temporal and spatial distance enabling them to make better, more collaborative decisions. Recent technological advancements have dramatically increased companies' ability to connect. Connectivity creates the capability to share information.

In this study, we propose that information sharing, joint decision making, and EDI are the relevant factors and suggest that operational performance is the most important one. The measurement instrument provided as a result of this study is useful for researchers who are interested in conducting survey-based research associated with operational performance measures in any sector. This study also provides an empirical explanation that identifies the positive and important relationship among supply chain management and operational performance within the context of the automotive industry in Pakistan. Thus, managers looking for proficiency and efficiency improvements should consider a set of supply chain management that could help them to expand their supply chain abilities and in turn their performance.

Supply chains consist of all associated activities, from raw material flows to good transformations. Management of the performance of supply chain activities in order to increase supply chain associations and the good advantage is an important (Alfalla-Luque, Machuca \& Marín-García, 2018). The supply chain management provided in this study can be suitable for managers to evaluate to their current performance of the automotive industry in Pakistan. Industry strongly interested in developing good performance and should develop innovative strategies. There is scope to enhance this study by taking different industries and increasing the number of respondents into consideration.

Manager's perspective, this study demonstrates why careful consideration should be applied when deciding which supply chain strategy should be developed. Firms that manage to achieve this relationship benefit greatly by improving their operating margins, cost efficiencies, waste reduction, agility, and time-to-market, and overall gain sustainable competitive advantages. This study also demonstrates that such a relationship cannot be achieved in isolation at a firm-level alone.

\section{Conclusion}

This study was conducted to understand how supply chain management approaches contribute to operational performance. The current study finds out the approaches to enhance the operational performance literature through information sharing, joint decision making, and EDI. It has been proved that information sharing, joint decision making, and Electronic Data Interchange have a direct and significant role in the performance of supply chain members of the automotive industry in Pakistan. This study shows the impact of three supply chain management approaches, information sharing, joint decision making and EDI with operational performance is positive and significant except EDI. In doing so it introduces a theoretical perspective of the potential deployment of supply chain management as a means to achieve operational performance. Overall, this study provides further awareness into the developing field of the relationships among supply chain management and performance measures. There are various other approaches and strategies available for enhancing performance, future research can be conducted on these approaches and comparison of these approaches with other industries.

\section{Declaration of Conflicting Interests}

The author declared no potential conflicts of interest with respect to the research, authorship, and/or publication of this article. 


\section{Funding}

The author received no financial support for the research, authorship, and/or publication of this article.

\section{References}

Abdallah, A.B., Obeidat, B.Y., \& Aqqad, N.O. (2014). The Impact of Supply Chain Management Practices on Supply Chain Performance in Jordan: The Moderating Effect of Competitive Intensity. International Business Research, 7(3), 13-27. https://doi.org/10.5539/ibr.v7n3p13

Afzal, M.A. (2011). Managing Risk and Resilience in Supply Chain \& 3PL: Conceptual Developments and Proposed Frameworks. Master Thesis. King Fahd University of Petroleum \& Minerals.

Ahmad, N., \& Saifudin, A.M. (2014). Supply Chain Management in Telecommunication Industry: The Mediating Role of Logistics Integration. ICTOM 04 - 4th International Conference on Technology and Operations Management Supply, 648-653.

Alfalla-Luque, R., Machuca, J.A.D., \& Marín-García, J.A. (2018). Triple-A and competitive advantage in supply chains: Empirical research in developed countries. International Journal of Production Economics, 203(May), 48-61. https://doi.org/10.1016/j.ijpe.2018.05.020

Anand, N., \& Grover, N. (2015). Measuring retail supply chain performance: Theoretical model using key performance indicators (KPIs). Benchmarking: An International Journal, 22(1), 135-166. https://doi.org/10.1108/BIJ-05-2012-0034

Arshinder, Kanda, A., \& Deshmukh, S.G. (2006). A coordination-based perspective on the procurement process in the supply chain. International Journal of Value Chain Management, 1(2), 117-138. https://doi.org/10.1504/IJVCM.2006.011181

Arzu-Akyuz, G., \& Erman-Erkan, T. (2010). Supply chain performance measurement: a literature review. International Journal of Production Research, 48(17), 5137-5155. https://doi.org/10.1080/00207540903089536

Ataseven, C., \& Nair, A. (2017). Assessment of Supply Chain Integration and Performance Relationships: A Meta-Analytic Investigation of the Literature. International Journal of Production Economics. https://doi.org/10.1016/j.ijpe.2017.01.007

Attia, A. (2015). Testing the effect of marketing strategy alignment and triple-A supply chain on performance in Egypt. EuroMed Journal of Business, 10(2), 163-180. https://doi.org/10.1108/EMJB-07-2014-0020

Basu, G., Jeyasingam, J., Habib, M., Letchmana, U., \& Ravindran, R. (2017). The Impact of Supply Chain Management Practices on the Performance of Private Universities in Malaysia. International Journal of Supply Chain Management, 6(3), 22-35.

Cao, M., Vonderembse, M.A., Zhang, Q., \& Ragu-Nathan, T.S. (2010). Supply chain collaboration: conceptualisation and instrument development. International Journal of Production Research, 48(22), 6613-6635. https://doi.org/10.1080/00207540903349039

Cao, M., \& Zhang, Q. (2011). Supply chain collaboration: Impact on collaborative advantage and firm performance. Journal of Operations Management, 29(3), 163-180. https://doi.org/10.1016/j.jom.2010.12.008

Cao, M., \& Zhang, Q. (2013). Supply Chain Collaboration: Roles of Interorganizational Systems, Trust, and Collaborative Culture (1-221). London: Springer. https://doi.org/10.1007/978-1-4471-4591-2

Chen, J. (2012). The Role of Supply Chain Collaboration in Supply Chain Risk Mitigation. Ph. D. Thesis. Monash University.

Chopra, S., \& Sodhi, M.S. (2004). Managing risk to avoid supply-chain breakdown. MIT Sloan Management Review, 46(1), 53.

Christopher, M. (2011). Logistics \& supply chain management. Pearson Education Limited (4 ${ }^{\text {th }}$ ed.). Pearsons. 
Christopher, M., Mena, C., Khan, O., \& Yurt, O. (2011). Approaches to managing global sourcing risk. Supply Chain Management: An International Journal, 16(2), 67-81. https://doi.org/10.1108/13598541111115338

Cook, L.S., Heiser, D.R., \& Sengupta, K. (2011). The moderating effect of supply chain role on the relationship between supply chain practices and performance: An empirical analysis. International Journal of Physical Distribution \& Logistics Management, 41(2), 104-134. https:/ / doi.org/10.1108/09600031111118521

Dow Chemical Company (2011). Dow Chemical: Strategies for Supply Chain Security and Sustainability. Available at: http://usresilienceproject.org/wp-content/uploads/2014/09/pdf-USRP Dow CS 012312.pdf

Effendi, F.S.R. (2015). The Determinants of Logistics Efficiency in Malaysia. Social Science Research Network. Available at: https://papers.ssrn.com/sol3/papers.cfm?abstract id=2702315

Elkins, D., Handfield, R.B., Blackhurst, J., \& Craighead, C.W. (2005). 18 Ways to Guard against Disruption. Supply Chain Management Review, 9(1), 46-52.

Florian, G.L., \& Constangioara, A. (2014). The impact of performances in romanian supply chains on organizational performances. Economia. Seria Management, 17(2), 265-275.

Flynn, B.B., Huo, B., \& Zhao, X. (2010). The impact of supply chain integration on performance: A contingency and configuration approach. Journal of Operations Management, 28(1), 58-71. https://doi.org/10.1016/j.jom.2009.06.001

Gunasekaran, A., \& Kobu, B. (2007). Performance measures and metrics in logistics and supply chain management: a review of recent literature (1995-2004) for research and applications. International Journal of Production Research, 45(12), 2819-2840. https://doi.org/10.1080/00207540600806513

Gunasekaran, A., Patel, C., \& McGaughey, R.E. (2004). A framework for supply chain performance measurement. International Journal of Production Economics, 87(3), 333-347. https://doi.org/10.1016/j.ijpe.2003.08.003

Ha, B.C., Park, Y.K., \& Cho, S. (2011). Suppliers' affective trust and trust in competency in buyers Its effect on collaboration and logistics efficiency. International Journal of Operations \& Production Management, 31(1-2), 56-77. https://doi.org/10.1108/01443571111098744

Hassan, A.A.B.M., Zaharudin, A.B., \& Yunus, A.B.M. (2015). Delays in physical distribution: a case study of sony supply chain solutions Malaysia. In The Proceedings of The 4th International Seminar on Entrepreneurship and Business (ISEB 2015) (658-674). Faculty of Entrepreneurship and Business, UMK.

Huo, B., Zhao, X., \& Zhou, H. (2014). The effects of competitive environment on supply chain information sharing and performance: An empirical study in China. Production and Operations Management, 23(4), 552-569. https://doi.org/10.1111/poms.12044

Jayaram, J., Tan, K.C., \& Nachiappan, S.P. (2010). Examining the interrelationships between supply chain integration scope and supply chain management efforts. International Journal of Production Research, 48(22), 6837-6857. https://doi.org/10.1080/00207540903358329

Jüttner, U., \& Maklan, S. (2011). Supply chain resilience in the global financial crisis: An empirical study. Supply Chain Management: An International Journal, 16(4), 246-259. https://doi.org/10.1108/13598541111139062

Kamalahmadi, M., \& Parast, M.M. (2016). A review of the literature on the principles of enterprise and supply chain resilience: Major findings and directions for future research. International Journal of Production Economics, 171, 116-133. https://doi.org/10.1016/j.ijpe.2015.10.023

Kauppi, K., Longoni, A., Caniato, F., \& Kuula, M. (2016). Managing country disruption risks and improving operational performance: risk management along integrated supply chains. International Journal of Production Economics, 182(August), 484-495. https://doi.org/10.1016/j.ijpe.2016.10.006

Li, G., Fan, H., Lee, P.K.C., \& Cheng, T.C.E. (2015). Joint supply chain risk management: An agency and collaboration perspective. International Journal of Production Economics, 164, 83-94.

https://doi.org/10.1016/j.ijpe.2015.02.021 
Maestrini, V., Luzzini, D., Maccarrone, P., \& Caniato, F. (2017). Supply Chain Performance Measurement Systems: A Systematic Review and Research Agenda. International Journal of Production Economics, 183(August 2015), $299-315$. https://doi.org/10.1016/j.ijpe.2016.11.005

Manners-Bell, J. (2014). Supply Chain Risk Understanding emerging threats to global supply chains. Kogan Page (1-262). Croydon: John Manners-Bell..

Marín-García, J.A., Alfalla-Luque, R., \& Machuca, J.A.D. (2018). A Triple-A supply chain measurement model: validation and analysis. International Journal of Physical Distribution and Logistics Management, 48(10), 976-994. https://doi.org/10.1108/IJPDLM-06-2018-0233

Pakistan Economic Survey (2016). Pakistan Economic Survey. http://finance.gov.pk/survey 1516.html

Qi, Y., Huo, B., Wang, Z., \& Yeung, H.Y.J. (2017). The impact of operations and supply chain strategies on integration and performance. International Journal of Production Economics, 185(July 2015), 162-174. https://doi.org/10.1016/j.ijpe.2016.12.028

Qrunfleh, S.M. (2010). Alignment of information systems with supply chains: Impacts on supply chain performance and organizational performance. Ph. D. Thesis. The University of Toledo.

Ross, D.F. (2011). Introduction To Supply Chain Management Technologies (2nd ed.). CRC Press.

Seo, Y.J., Dinwoodie, J., \& Roe, M. (2015). Measures of supply chain collaboration in container logistics. Maritime Economics \& Logistics, 17(3), 292-314. https://doi.org/10.1057/mel.2014.26

Sezen, B. (2008). Relative effects of design, integration and information sharing on supply chain performance. Supply Chain Management: An International Journal, 13(3), 233-240.

Shahbaz, M.S., Chandio, A.F., Oad, M., Ahmed, A., \& Ullah, R. (2018). Stakeholders' Management Approaches in Construction Supply Chain: a New Perspective of Stakeholder's Theory. International Journal of Sustainable Construction Engineering \& Technology, 9(2), 16-26.

Shahbaz, M.S., Kazi, A.G., Othman, B., Javaid, M., Hussain, K., \& Rasi, R.Z.R.M. (2019). Identification, Assessment and Mitigation of Environment Side Risks for Malaysian Manufacturing. Engineering, Technology \& Applied Science Research, 9(1), 3851-3857.

Shahbaz, M.S., Rasi, R.Z., Bin, M.D.F., \& Rehman, F. (2017). What is supply chain risk management? A review. Advanced Science Letters, 23(9), 9233-9238. https://doi.org/10.1166/asl.2017.10061

Shahbaz, M.S., Rasi, R.Z., Bin, M.D.F., \& Sohu, S. (2018). The impact of supply chain collaboration on operational performance: Empirical evidence from manufacturing of Malaysia. International Journal of Advanced and Applied Sciences, 5(8), 64-71. https://doi.org/10.21833/ijaas.2018.08.009

Shahbaz, M.S., Rasi, R.Z., Zulfakar, M.H., Bin, M.D.F., \& Asad, M.M. (2018). Theoretical Framework Development for Supply Chain Risk Management for Malaysian Manufacturing. International Journal of Supply Chain Management, $7(6), 325-338$.

Shahbaz, M.S., Rasi, R.Z., Zulfakar, M.H., Bin, M.D.F., Abbas, Z., \& Mubarak, M.F. (2018). A Novel Metric of Measuring Performance for Supply Chain Risk Management: Drawbacks and Qualities of Good Performance. Journal of Fundamental and Applied Sciences, 10(3S), 967-988. http://dx.doi.org/10.4314/jfas.v10i3s.83

Sheu, C., Yen, H.R., \& Chae, B. (2006). Determinants of supplier-retailer collaboration: evidence from an international study. International Journal of Operations \& Production Management, 26(1), 24-49.

Shukla, R.K. (2016). Coordination Practices in Supply Chain Management: An Empirical Study of Indian Manufacturing Firms. Journal of Management Research, 16(1), 44-54.

Shukla, R.K., Garg, D., \& Agarwal, A. (2011). Understanding of supply chain: A literature review. International Journal of Engineering Science and Technology, 3(3), 2059-2072. 
Shukla, R.K., Garg, D., \& Agarwal, A. (2013). Supply Chain Coordination Competency and Firm Performance: An Empirical Study. International Journal of Supply Chain Management, 2(4), 64-70.

Singh, A. (2013). Understanding supply chain disruption risk with the aid of social networks and information flows analysis. Ph. D. Thesis. Aston University.

Sukati, I., Hamid, A.B., \& Baharun, R. (2013). Testing the Effect of the Supply Chain Management Implementation on Business Performance: An Empirical Study. International Business Research, 6(1), 76-89.

https://doi.org/10.5539/ibr.v6n1p76

Sukati, I., Hamid, A.B., Baharun, R., \& Yusoff, R.M. (2012). The Study of Supply Chain Management Strategy and Practices on Supply Chain Performance. Procedia - Social and Behavioral Sciences, 40, 225-233.

https://doi.org/10.1016/j.sbspro.2012.03.185

Sundram, V.P.K., Chandran, V., \& Bhatti, M.A. (2016). Supply chain practices and performance: the indirect effects of supply chain integration. Benchmarking: An International Journal, 23(6), 1445-1471.

https://doi.org/10.1108/02656710210415703

Sundram, V.P.K., Ibrahim, A.R., \& Govindaraju, V.G.R.C. (2011). Supply chain management practices in the electronics industry in Malaysia. Benchmarking: An International Journal, 18(6), 834-855.

https://doi.org/10.1108/14635771111180725

Whitten, G.D., Kenneth, W.G., \& Zelbst, P.J. (2012). Triple-A supply chain performance. International Journal of Operations and Production Management, 32(1), 28-48. https://doi.org/10.1108/01443571211195727

Wiengarten, F., Humphreys, P., Cao, G., Fynes, B., \& McKittrick, A. (2010). Collaborative supply chain practices and performance: exploring the key role of information quality. Supply Chain Management-an International Journal, 15(6), 463-473. https://doi.org/10.1108/13598541011080446

Journal of Industrial Engineering and Management, 2019 (www.jiem.org)

\section{(ब) (1) (}

Article's contents are provided on an Attribution-Non Commercial 4.0 Creative commons International License. Readers are allowed to copy, distribute and communicate article's contents, provided the author's and Journal of Industrial Engineering and Management's names are included. It must not be used for commercial purposes. To see the complete license contents, please visit https://creativecommons.org/licenses/by-nc/4.0/. 